\title{
Islet amyloid polypeptide amide causes peripheral insulin resistance in vivo in dogs
}

\author{
R. Sowa, T. Sanke, J. Hirayama, H. Tabata, H. Furuta, S. Nishimura and K. Nanjo \\ First Department of Medicine, Wakayama University of Medical Science, Wakayama, Japan
}

\begin{abstract}
Summary. Islet amyloid polypeptide is a 37 amino acid hormone-like peptide which is the major protein component of islet amyloid deposits commonly found in patients with Type 2 (non-insulin-dependent) diabetes mellitus. Recent studies indicate that a physiologically active form of this peptide appears to be carboxyamidated and secreted from the insulin-producing beta cell. In order to clarify the possible in vivo actions of islet amyloid polypeptide, we have studied the effects of synthesized islet amyloid polypeptide-amide on peripheral glucose utilization by performing hyperinsulinaemic euglycaemic glucose clamp studies on dogs. Exogenously administered islet amyloid polypeptide-amide (an infusion
\end{abstract}

from 1.0 to $100 \mu \mathrm{g} \cdot \mathrm{kg}^{-1} \cdot \mathrm{h}^{-1}$, over $2 \mathrm{~h}$ ) inhibited the insulinstimulated glucose disposal rate in a dose dependent manner. Twenty-five $\mu \mathrm{g} \cdot \mathrm{kg}^{-1} \cdot \mathrm{h}^{-1}$ of islet amyloid polypeptide-amide infused via a peripheral vein significantly lowered the glucose disposal rate by $20 \%$ (from $17.4 \pm 1.7$ to $14.4 \pm 1.7 \mathrm{mg}$. $\mathrm{kg}^{-1} \cdot \min ^{-1}, n=5, p<0.01$ ). These findings suggest that islet amyloid polypeptide-amide causes peripheral insulin resistance in vivo.

Key words: Islet amyloid polypeptide, amylin, amidation, in vivo effect, insulin resistance, diabetes mellitus.
Islet amyloid polypeptide (IAPP/amylin) is a 37 amino acid peptide, which is the major protein component of islet amyloid deposits, as shown by Westermark et al. [1] and Cooper et al. [2]. This peptide appears to be a normal product of the insulin-producing beta cell $[2,3]$. Recently Sanke et al. [4] identified and characterized a cDNA encoding the human IAPP. The nucleotide sequence of the clone suggests that a physiologically active form of IAPP is released from its precursor by proteolytic processing and is secreted by the beta cell in a carboxyamidated form. These observations suggest that IAPP may be a normal islet hormone.

Recent studies suggest that IAPP may be involved in the pathogenesis of Type 2 (non-insulin-dependent) diabetes mellitus, Cooper et al. reported that both native IAPP extracted from human diabetic pancreas and purified by HPLC [5] and synthesized IAPP-carboxylate (IAPP-COOH) [6] cause resistance to insulin in the rat skeletal muscle in vitro. In order to clarify the possible in vivo action of IAPP, the effects of synthesized human IAPP-amide (IAPP-NH$)_{2}$ ) on insulin-stimulated glucose utilization were studied on dogs using the hyperinsulinaemic euglycaemic glucose clamp technique (h-EGCT) [7].

\section{Materials and methods}

Synthesis of IAPP-NH $\mathrm{H}_{2}$ and IAPP-COOH

Human IAPP- $\mathrm{NH}_{2}$ and IAPP-COOH were assembled by using an Applied Biosystems model $430 \mathrm{~A}$ peptide synthesizer [(software version 1.40) Applied Biosystems, Foster City, Calif., USA] with HMBA-resin (for C-terminal amide) and Pam-resin (for C-terminal carboxylic acid) as the solid support. The final peptide resins were treated with anhydrous hydrogen fluoride in the presence of $20 \% \mathrm{p}$ cresol at $-5^{\circ} \mathrm{C}$ for $60 \mathrm{~min}$. After evaporation of excess hydrogen fluoride, the crude peptides were precipitated with ether and extracted with trifluoroacetic acid to filter off the solid supports. The crude products containing sulfohydryl groups were treated with $\mathrm{K}_{3} \mathrm{Fe}(\mathrm{CN})_{6}$ at a concentration of $0.1 \mathrm{mmol} / 1$ in aqueous $1 \mathrm{~mol} / 1$ $\mathrm{NH}_{4} \mathrm{OAc}$ containing $8 \mathrm{~mol} / \mathrm{l}$ urea for $30 \mathrm{~min}$. The crude products were then purified by preparative reverse-phase HPLC. The homogeneity of the final product was confirmed by analytical HPLC, capillary electrophoresis and amino acid analysis.

\section{Hyperinsulinaemic euglycaemic glucose clamp test}

Seven mongrel dogs weighing from 9 to $12 \mathrm{~kg}$ were subjected to $\mathrm{h}$ EGCT under pentobarbital anaesthesia after an overnight fast. Human insulin (Novo Industry, Copenhagen, Denmark) at a rate of 
Table 1. Dose dependent effect of IAPP- $\mathrm{NH}_{2}$ on glucose disposal rate in hyperinsulinaemic euglycaemic glucose clamp study

\begin{tabular}{llll}
\hline $\begin{array}{l}\text { IAPP-NH } \\
\text { Infusion rate } \\
\left(\mu \mathrm{g} \cdot \mathrm{kg}^{-1} \cdot \mathrm{h}^{-1}\right)\end{array}$ & \multicolumn{3}{l}{ Change of glucose disposal rate $(\%)$} \\
\cline { 2 - 4 } & Before & During & After \\
\hline $1.0(n=1)^{\mathrm{a}}$ & 100 & 100.4 & \\
$2.5(n=1)^{\mathrm{b}}$ & 100 & 100.2 & \\
$10.0(n=1)^{\mathrm{a}}$ & 100 & 93.9 & \\
$25.0(n=1)^{\mathrm{b}}$ & 100 & 84.2 & \\
$50.0(n=1)^{\mathrm{a}}$ & 100 & 79.9 & \\
$100.0(n=1)^{\mathrm{b}}$ & 100 & 73.3 & \\
\hline $2.5(n=3)$ & 100 & $101.0 \pm 3.8 \mathrm{NS}$ & $104.8 \pm 5.1 \mathrm{NS}$ \\
$25.0(n=5)$ & 100 & $81.9 \pm 3.4^{\mathrm{c}}$ & $91.5 \pm 6.4 \mathrm{NS}$ \\
\hline
\end{tabular}

$\overline{a, b}$ experiment performed on the same dog. Significance of the difference from basal (before): ${ }^{\mathrm{c}} p<0.01$, NS; not significant.

Before, during, after: last $30 \mathrm{~min}$ of every $120 \mathrm{~min}$ period before, during and after IAPP-NH $\mathrm{N}_{2}$ infusion, respectively

$5 \mathrm{mU} \cdot \mathrm{kg}^{-1} \cdot \mathrm{min}^{-1}$ was infused through a peripheral vein. Arterialized venous blood glucose concentrations were measured every 2 min by glucose oxidase method using Glucose MONITOR GM1320 (Kyoto Dai-ichi Kagaku Co. Ltd., Kyoto, Japan). Glucose ( $25 \%$ solution) was infused via a peripheral vein to maintain the fasting blood glucose level and the glucose disposal rate (GDR) [7] was calculated. IAPP-NH $\mathrm{NH}_{2}\left(1\right.$ to $\left.100 \mu \mathrm{g} \cdot \mathrm{kg}^{-1} \cdot \mathrm{h}^{-1}\right)$ or IAPP-COOH $\left(25 \mu \mathrm{g} \cdot \mathrm{kg}^{-1} \cdot \mathrm{h}^{-1}\right)$ was infused over $2 \mathrm{~h}$ through a peripheral vein 120 min after the start of h-EGCT.

\section{Statistical Analysis}

The data are shown as mean \pm SEM. The statistical analysis was done by the paired Student's $t$-test and a $p$ value less than 0.05 was considered significant.

\section{Results}

Sufficiently high and constant plasma insulin concentration $(206 \pm 6.7 \mu \mathrm{U} / \mathrm{ml})$ was achieved by the i. v. infusion of $5 \mathrm{mU} \cdot \mathrm{kg}^{-1} \cdot \mathrm{min}^{-1}$ insulin. A constant GDR was obtained $90 \mathrm{~min}$ after the start of h-EGCT, and it continued for at least $7 \mathrm{~h}$ without IAPP infusion.

The mean percent change of GDR for the last $30 \mathrm{~min}$ of every $120 \mathrm{~min}$ period before, during and after IAPP$\mathrm{NH}_{2}$ infusion is shown in Table 1 . For a preliminary study, several doses of IAPP-NH${ }_{2}$ were infused in two dogs (upper panel of Table 1). The IAPP-NH ${ }_{2}$ infusion lowered the GDR in a dose dependent manner. A decrease of more than $15 \%$ in the GDR was noted at an infusion rate of $25 \mu \mathrm{g} \cdot \mathrm{kg}^{-1} \cdot \mathrm{h}^{-1}$ or more. When $25 \mu \mathrm{g} \cdot \mathrm{kg}^{-1} \cdot \mathrm{h}^{-1}$ IAPP$\mathrm{NH}_{2}$ was infused over $2 \mathrm{~h}$, the GDR began to fall $30 \mathrm{~min}$ after the start of the infusion. Obvious decline of the GDR was observed through the latter half of the infusion, and continued for about $80 \mathrm{~min}$ after discontinuation of the infusion (Fig. 1). A significant decline in the GDR was noted during the $25 \mu \mathrm{g} \cdot \mathrm{kg}^{-1} \cdot \mathrm{h}^{-1}$ IAPP- $\mathrm{NH}_{2}$ infusion (from $17.7 \pm 1.7$ to $\left.14.4 \pm 1.7 \mathrm{mg} \cdot \mathrm{kg}^{-1} \cdot \mathrm{min}^{-1}, n=5, p<0.01\right)$. However, the GDR was not changed by the $2.5 \mu \mathrm{g} \cdot \mathrm{kg}^{-1}$. $\mathrm{h}^{-1}$ IAPP- $\mathrm{NH}_{2}$ infusion (lower panel of Table 1 ).

In one dog the same dose $\left(25 \mu \mathrm{g} \cdot \mathrm{kg}^{-1} \cdot \mathrm{h}^{-1}\right)$ of IAPP$\mathrm{NH}_{2}$ or IAPP-COOH was infused via a peripheral vein
(Fig. 1). The decline in the GDR induced by IAPP-COOH was markedly reduced compared with that induced by IAPP-NH ${ }_{2}$. When the same dose of IAPP-NH $\mathrm{NH}_{2}$ was infused through the portal vein in the same dog, the decline in the GDR was also reduced (Fig.1).

\section{Discussion}

Islet amyloid deposits are found in the pancreas of $>90 \%$ of patients with Type 2 diabetes mellitus [3]. Their possible role in the development of Type 2 diabetes mellitus has been disputed. In 1987, an amyloid fibril was extracted and characterized from the islet amyloid deposits. However, the C-terminal residue of this novel peptide (IAPP [1] / Amylin [2]) was not reported to be Tyr-amide. Using native IAPP extracted from human diabetic pancreas, Leighton and Cooper [5] reported that $1 \times 10^{-9}$ $\mathrm{mol} / \mathrm{l}$ native IAPP inhibits both basal and insulin-stimulated rates of glycogen synthesis in stripped rat soleus muscle in vitro. The same result was obtained by Cooper et al. [6] using $1.2 \times 10^{-7} \mathrm{~mol} / \mathrm{l}$ synthesized IAPP-COOH. Recent studies, however, indicate that a physiologically active form of IAPP should be carboxyamidated [4]. The present study was thus designed to examine the effects of synthesized IAPP-NH ${ }_{2}$ on insulin sensitivity in the peripheral tissue by employing the h-EGCT. This study clarified an in vivo action of exogenously administered IAPP- $\mathrm{NH}_{2}$. That is, IAPP- $\mathrm{NH}_{2}$ inhibited insulin-stimulated glucose metabolism. It was also discovered that IAPP-COOH has less effect than IAPP-NH $\mathrm{NH}_{2}$ (Fig. 1). This finding may account for the much higher activity observed by Leighton and Cooper [5] in experiments with native IAPP, as opposed to material synthesized with free acid C-terminus

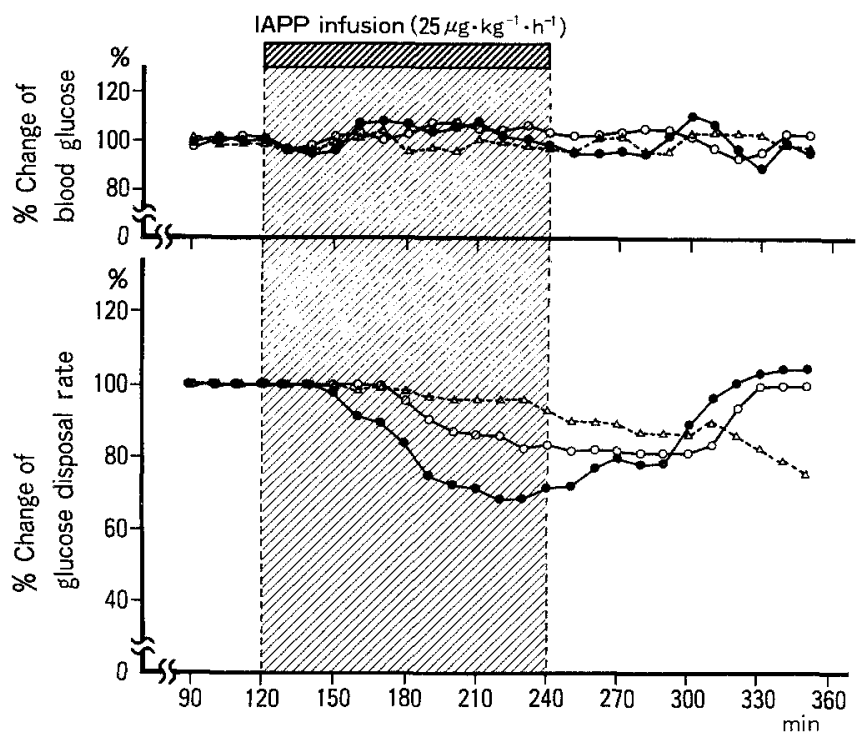

Fig. 1. Percent changes in blood glucose and glucose disposal rate during hyperinsulinaemic euglycaemic glucose clamp technique with $25 \mu \mathrm{g} \cdot \mathrm{kg}^{-1} \cdot \mathrm{h}^{-1}$ islet amyloid polypeptide (IAPP)- $\mathrm{NH}_{2}$ or IAPP-COOH infusion performed on the same dog. Closed circle with solid line: IAPP-NH $\mathrm{N}_{2}$ into peripheral vein, open circle with solid line: IAPP- $\mathrm{NH}_{2}$ into portal vein, and open triangle with dashed line: IAPP-COOH into peripheral vein 
(IAPP-COOH) [6], if the native IAPP is carboxyamidated.

Calcitonin gene-related peptide which has partial amino acid sequence identity with IAPP has been reported to cause both hepatic and peripheral insulin resistance [8]. Thus, the possibility arises that the decline of GDR during IAPP-NH $\mathrm{N}_{2}$ infusion is due to the increased hepatic glucose output induced by IAPP- $\mathrm{NH}_{2}$, although the peripheral insulin concentration in all h-EGCTs reached about $200 \mu \mathrm{U} / \mathrm{ml}$ which is thought to be enough to suppress hepatic glucose output $[7,9]$. However, we have evidence that IAPP- $\mathrm{NH}_{2}\left(10^{-7} \sim 10^{-12} \mathrm{~mol} / \mathrm{l}\right)$ does not stimulate hepatic glucose output in rat liver perfusion systems (data not shown). IAPP- $\mathrm{NH}_{2}$ thus may cause insulin resistance in the peripheral tissue, although the observed effects could conceivably be mediated through alterations in blood flow and/or the sympathetic nervous system.

Our result, obtained in vivo, is consistent with that observed in vitro by Leighton and Cooper [5] and by Cooper et al. [6], although the peripheral concentration of infused IAPP-NH $\mathrm{N}_{2}$ could not be determined in this study. The significant inhibitory effect of IAPP-NH $\mathrm{N}_{2}$ was noted at the infusion rate of $25 \mu \mathrm{g} \cdot \mathrm{kg}^{-1} \cdot \mathrm{h}^{-1}$. While the effect could not be seen at the infusion rate of $2.5 \mu \mathrm{g} \cdot \mathrm{kg}^{-1} \cdot \mathrm{h}^{-1}$. These results will allow us to re-evaluate whether the inhibitory effect of IAPP-NH $\mathrm{NH}_{2}$ is due to a physiological or pharmacological action once a sensitive and specific assay to measure the plasma IAPP- $\mathrm{NH}_{2}$ concentration has been developed. Interpretation of our results must take into account the fact that chemically synthesized human IAPP was used on dogs. The homogeneity was checked by analytical reverse phase HPLC, capillary electrophoresis and amino acid analysis, but not by first atomic bombardment mass spectrometry.

The inhibitory effect of IAPP- $\mathrm{NH}_{2}$ on insulin-stimulated glucose metabolism was reduced when it was infused via the portal vein (Fig. 1). This fact suggests that the liver may play some important role in the action/degradation of IAPP-NH $\mathrm{NH}_{2}$. From such a point of view, further investigation is necessary to clarify the physiological action of IAPP- $\mathrm{NH}_{2}$.

Acknowledgements. We are indebted to Dr. K. Nakajima, Protein Research Foundation Peptide Institute Inc., Osaka, Japan, for sup- plying the synthesized human islet amyloid polypeptide. This work was supported by a Grant-in-Aid for Scientific Research (No. 01480294) from the Ministry of Education, Science and Culture of Japan.

\section{References}

1. Westermark P, Wernstedt C, Wilander E, Hayden DW, O'Brien TD, Johnson KH (1987) Amyloid fibrils in human insulinoma and islets of Langerhans of the diabetic cat are derived from a neuropeptide-like protein also present in normal islet cells. Proc Natl Acad Sci USA 84: 3881-3885

2. Cooper GJS, Willis AC, Clark A, Turner RC, Sim RB, Reid KBM (1987) Purification and characterization of a peptide from amyloid-rich pancreases of type 2 diabetic patients. Proc Natl Acad Sci USA 84: 8628-8632

3. Westermark P, Wilander E, Westermark GT, Johnson KH (1987) Islet amyloid polypeptide-like immunoreactivity in the islet $\mathrm{B}$ cells of Type 2 (non-insulin-dependent) diabetic and non-diabetic individuals. Diabetologia 30: 887-892

4. Sanke T, Bell GI, Sample C, Rubenstein AH, Steiner DF (1988) An islet amyloid peptide is derived from an 89 -amino acid precursor by proteolytic processing. J Biol Chem 263: 17243-17246

5. Leighton B, Cooper GJS (1988) Pancreatic amylin and calcitonin gene-related peptide cause resistance to insulin in skeletal muscle in vitro. Nature 335: 632-635

6. Cooper GJS, Leighton B, Dimitriadis GD, Parry-Billings M, Kowalchuk JM, Howland K, Rothbard JB, Willis AC, Reid KBM (1988) Amylin found in amyloid deposits in human type 2 diabetes mellitus may be a hormone that regulates glycogen metabolism in skeletal muscle. Proc Natl Acad Sci USA 85: 7763 7766

7. DeFronzo RA, Tobin JD, Andres R (1979) Glucose clamp technique: a method for quantifying insulin secretion and resistance. Am J Physiol 237: E214-E223

8. Molina JM, Cooper GJS, Olefsky JM (1989) Calcitonin gene related peptide causes insulin resistance in vivo. Clin Res 37: 456A

9. Rizza RA, Mandrarino LJ, Gerich JE (1981) Dose-response characteristics for effects of insulin on production and utilization of glucose in man. Am J Physiol 240: E630-E639

Received: 14 August 1989

and in revised form: 12 October 1989

Dr. T. Sanke

The First Department of Medicine

Wakayama University of Medical Science

27 Nanaban-cho

Wakayama 640

Japan 